\title{
Landslides and lateral spreading triggered by the 24 January 2020 Sivrice earthquake (East Anatolian Fault)
}

\author{
24 Ocak 2020 Sivrice depreminin (Doğu Anadolu Fayı) tetiklediği heyelan ve yanal \\ yayılmalar
}

\author{
Mehmet KÖKÜ̈$M^{* 1, a}$ \\ ${ }^{1}$ Fırat Üniversitesi, Mühendislik Fakültesi, Jeoloji Mühendisliği Bölümü, 23100, Elazı̆̆
}

• Geliş tarihi / Received: 09.02.2021 • • Düzeltilerek geliş tarihi / Received in revised form: 25.04.2021• Kabul tarihi / Accepted: 02.05 .2021

\begin{abstract}
On 24 January 2020, a devastating earthquake struck the town of Sivrice in Elazı ̆̆ province at 20:55 local time (17:55 UTC), resulting in 41 death and significant loss of property. The magnitude of the earthquake was determined to be Mw 6.8 and strong shaking of main shock lasted about 20 seconds. The Sivrice earthquake triggered about 30 landslides over an area of $\sim 55 \mathrm{~km}^{2}$. This article presents the preliminary results of comprehensive study on mapping of the distribution of landslides, lateral spreading and other ground damaged effects triggered by the Sivrice earthquake occurred on the East Anatolian Fault. Following Sivrice earthquake, based on detailed on-ground field studies: (1) The Sivrice earthquake produced fewer landslides than empirical prediction for shallow earthquakes of these magnitudes (Mw 6.8) would suggest; (2) the Sivrice earthquake triggered extensive lateral spreading in Holocene age river banks, and result in the ground tears, opening surface cracks and fissure on flat ground; (3) primary surface rupture was not produced by Sivrice earthquake.
\end{abstract}

Keywords: Earthquake, East Anatolian Fault, Landslide, Lateral spreading

$\ddot{O} z$

24 Ocak 2020 tarihinde yerel saat ile 20:55' te (17:55 UTC) Elazı̆̆ ili Sivrice ilçesinde büyük bir deprem meydana gelmiş ve neticesinde 41 kişi hayatını kaybederken önemli maddi kayıplara yol açmıştır. Depremin aletsel büyüklüğü Mw 6,8 olup, kaynak alanda 20 sn. sürmüştür. Sivrice depremi $\sim 5 \mathrm{~km}^{2}$ bir alanda 30 civarında heyelan tetiklemiştir. Bu makale, Doğu Anadolu Fayı'nda meydana gelen Sivrice depreminin tetiklediği heyelanların dă̆ılımını, yanal yayılmayı ve diğer yüzey deformasyonlarının haritalandırılmasına ilişkin kapsamlı bir arazi çalışmasının sonuçlarını sunmaktadır. Sivrice depreminin ardından gerçekleştirilen ayrıntılı saha çalışmalarına dayanarak: (1) Sivrice depremi, bu büyüklüklerdeki sığ depremler için (Mw 6.8) ampirik bağıntılarla hesaplanan tahminlere göre daha az heyelan üretti; (2) Sivrice depremi Holosen yaşlı nehir kıyılarında geniş yanal yayılmaları tetikledi ve zemin yırtılmalarına, yüzey çatlaklarına ve büyük yarıklara neden oldu; (3) birincil yüzey kırılması (yer değiştirme) Sivrice depremi tarafindan üretilmedi.

Anahtar kelimeler: Deprem, Doğu Anadolu Fayl, Heyelan, Yanal yayılma

\footnotetext{
${ }^{\text {*a }}$ Mehmet KÖKÜM; mkokum@firat.edu.tr; Tel: (424) 237 00 00; orcid.org/0000-0001-5149-3931
} 


\section{Introduction}

Many of people in Turkey live in or close to seismically active area due to its proximity to the fault lines such as East and North Anatolian Faults, Aegean grabens, etc., have experienced two deadliest earthquakes in the world in 2020. A devastating earthquake occurred at 20:55 local time (17:55 GMT) centered on $8 \mathrm{~km}$ beneath the Çevrimtaş town of Sivrice in Elazı̆ province caused 41 fatalities and 1600 injuries (AFAD). Based on several seismological observatories and institutes including AFAD, KOERI, USGS, the magnitude of earthquake estimated as Mw 6.6 or 6.8 with depth in range from 5 to $10 \mathrm{~km}$. Great numbers of aftershocks were located along the trace of the 2020 rupture, tending to concentrate near the ends of the rupture. Aftershocks were strong and frequent include one on 25 January 2020 with magnitude of 5.1 , four others equal M 5 or greater, twenty larger than $\mathrm{M} \mathrm{4}$, and about 3,000 smaller than M 3 in the first year of the main event.
There are several remotely triggered events include the most remarkable one on 27 December 2020 (Mw 5.3) occurred on other structures, away from the EAF itself, such as the Uluova secondary fault zones, has not been mapped in detail in the area (Köküm and Inceöz, 2018, 2020).

The East Anatolian Fault (EAF) is a left-lateral strike-slip fault that extends between Karlova (Bingöl) in the northeast and Iskenderun Bay in the southwest (Arpat and Şaroğlu, 1972; Jackson and McKenzie, 1984; Şengör et al., 1985; Lyberis et al., 1992; Şaroğlu et al., 1992). It forms the tectonic boundary between Anatolian and Arabian plates. A recent study by Duman and Emre (2013) divides the EAF into three main sections with several subsegments: the southern (main) branch, the northern strand (Sürgü-Misis fault) and the Karasu trough. On 24 January 2020, a devastating Mw 6.8 earthquake occurred in the Pütürge segment of the southern (main) section of the East Anatolian Fault (EAF) (Figure 1).

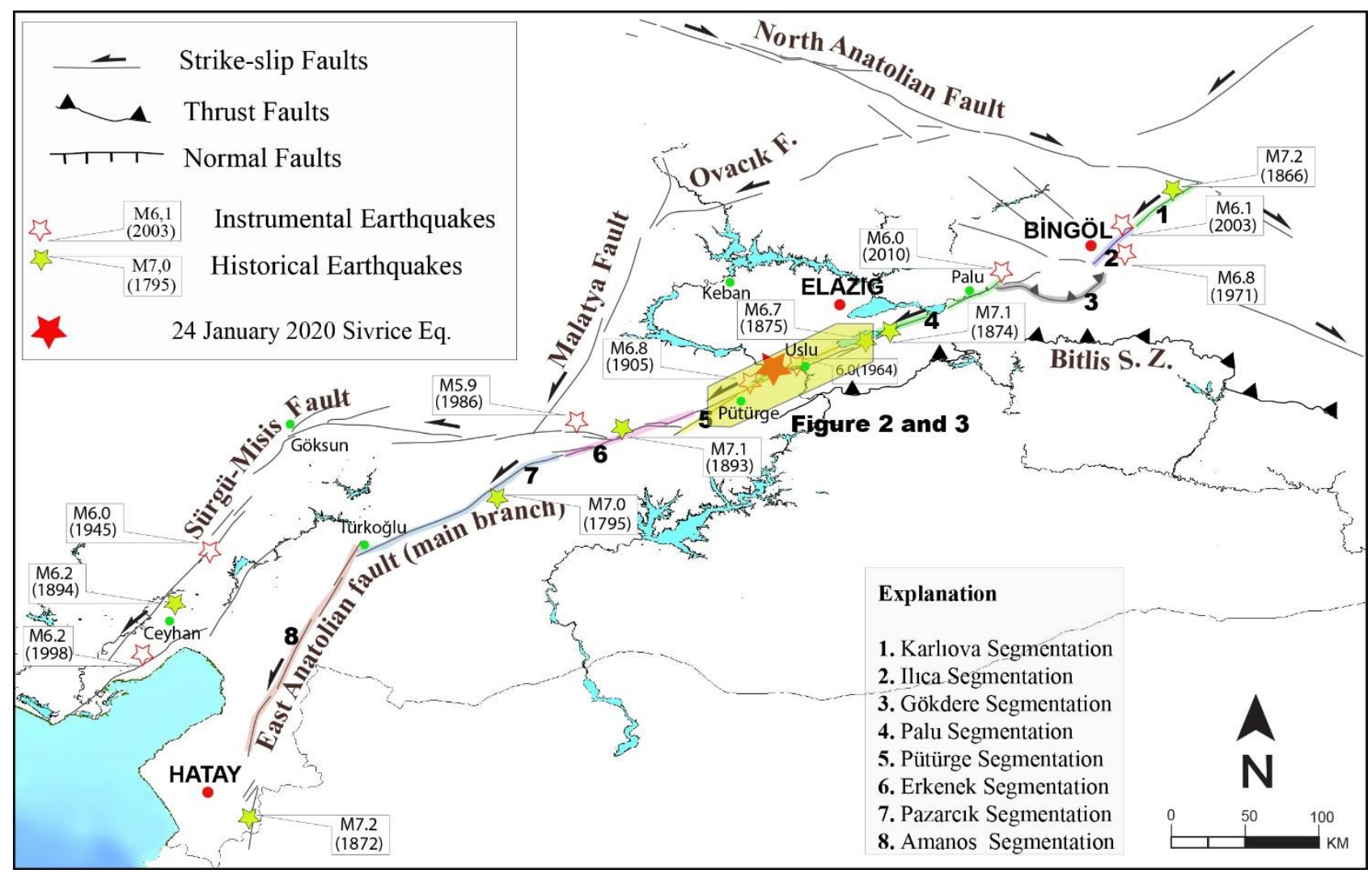

Figure 1. Tectonic map of Eastern Anatolia, and historical and instrumental seismicity along the EAF. Historical earthquakes modified from Duman and Emre (2013) (Ambraseys, 1989; Ambraseys and Finkel, 1995; Ambraseys and Jackson, 1998; Tan et al., 2008; Palutoğlu and Şaşmaz, 2017). Instrumental seismicity (KOERI, 2020).

The $96 \mathrm{~km}$ long Pütürge segment runs between the Lake Hazar releasing bend and Yarpuzlu restraining double bend. The Pütürge segment has several sub-sections with lengths vary from 21 to
$28 \mathrm{~km}$. Many large earthquakes have occurred on the EAF in historical and instrumental periods (Duman and Emre, 2013; Köküm and Özçelik, 2020) (Figure 1). There; however, are only two 
large known historic earthquakes on the Pütürge segment of the EAF, the most recent in 1905 Pütürge, and before that one in 1875 Lake Hazar (Ambraseys, 1989; Ambraseys and Jackson, 1998). The 1875 (Ms 6.7) and 1905 (Ms 6.8) earthquakes might have been ruptured on northern and southern sub-segments, hence central part should have been unbroken till 24 January 2020.

After the Sivrice earthquake, some studies were made by few researchers, which are mostly based on off-ground (seismology, GNSS, InSAR etc.) studies (Xu et al. 2020; Bletery et al., 2020; Pousse Beltran et al., 2020), and less on-ground field studies (Tatar et al., 2020; Kürçer et al., 2020; Sayin et al., 2020). Based on studies consist of monitoring with GNSS and InSAR suggest that about $50 \mathrm{~km}$ section of the Pütürge segment was ruptured (Xu et al. 2020; Bletery et al., 2020; Pousse Beltran et al., 2020). On the basis of onground field studies, coseismic surface rupture does not show a significant horizontal component and is probably mostly gravitational (Tatar et al., 2020; Kürçer et al., 2020; Sayın et al., 2021). One of the most detailed field reports by Kürçer et al., (2020) suggests that surface deformation features (Riedel shear fractures, en-échelon tension cracks, etc.) were observed along approximately $50-\mathrm{km}$ long section of Pütürge segment in the area between Lake Hazar and Pütürge. The most interesting finding of that study is that the recording the trace of surface rupture on the Euphrates river. Although there are several surface deformations were observed during field studies, Kürçer et al., (2020) did not document notably permanent ground displacements. On the basis of Tatar et al., (2020), surface deformations were observed in the area between Gezin (Elazı $\breve{g}$ ) and Ormaniçi (Pütürge) villages; they are classified into two as seismotectonic and seismogravitational features. Interferometric SAR (DInSAR) studies indicate that at least 30-km-long section of the Pütürge segment in the area between southwest of Sivrice and Pütürge is broken during the main shock. Tatar et al., (2020) discussed lack of surface rupturing earthquake, and they stated that it could be related a few reasons such as faultbend geometry, existing of Pütürge metamorphic rocks in the region and the earthquake didn't reach the surface.

I conducted on-ground field survey immediately after Sivrice earthquake to document the general distribution and extend of landslides, lateral spreading, and to seek evidence of primary surface fault rupture (surface displacement) generated by this earthquake. Preliminary results from these field surveys are presented in this paper.

\section{Geological setting}

Turkey is located in one of the most seismically active area with the collision of the Arabian, African, Eurasian and Anatolian plates (McKenzie, 1972). Inconsequence of these collision, primary deformation structures have developed in Turkey, such as the North and East Anatolian faults, Aegean grabens, Bitlis Zagros Suture Zone (BSZS). The EAF, Turkey's second active fault, is a continental transform fault that forms part of the tectonic boundary between the Anatolian plate and the African plate. The strike-slip fault is characterized by mainly lateral motion in a sinistral sense, where the eastern (African) plate moves northward relative to the western (Anatolian) plate.

The Bingöl earthquake on 22 May 1971 attracted attention to activity on the fault. In the studies after the earthquake accomplished by Seymen and Aydın (1972) and Arpat and Saroğlu (1972; 1975), EAF was mapped for the first time on a regional. The EAF has been studied by many researchers since the early 1960s. Altinl (1963) mapped the fault between Karlova and Bingöl on 1/500.000 scale maps prepared by MTA. The EAF was connected with North Anatolian Fault (NAF) in the north and Dead Sea Fault (DSF) in the south by Allen (1969).

Several authors have proposed segmentation of the EAF into subsegments based on its geometry and seismic behaviour: five were proposed by Hempton and Dewey (1981) six by Şaroğlu et al., (1992), fourteen by Barka and Kadinsky-Cade (1988) and eleven by Herece (2008). EAF extends between Karlıova (Bingöl) in the northeast and Iskenderun Bay in the southwest, a distance of about $580 \mathrm{~km}$. A recent study (Duman and Emre, 2013) divides the EAF into three main sections with several subsegments: the southern (main) branch, the northern strand (Sürgü-Misis fault) and the Karasu trough. On 24 January 2020, a devastating Mw 6.8 earthquake occurred in the Pütürge segment of the southern (main) section of the EAF (Figure 1 and 2).

Geological and morphological features in different parts of the EAF reveal left-lateral offsets which cluster around 9 to $30 \mathrm{~km}$ (Arpat and Şaroğlu, 1975; Hempton 1985; Herece and Akay 1992; Saroglu et al., 1992; Westaway and Arger 2001; Westaway 2003; Herece 2008). The Pütürge segment is home to around $22 \mathrm{~km}$ lateral offset on 
middle Eocene volcanic rocks, and $13 \mathrm{~km}$ lateral offset on the Euphrates river valley (Hempton,

1985) suggest high tectonic activity on this fault segment (Figure 2).

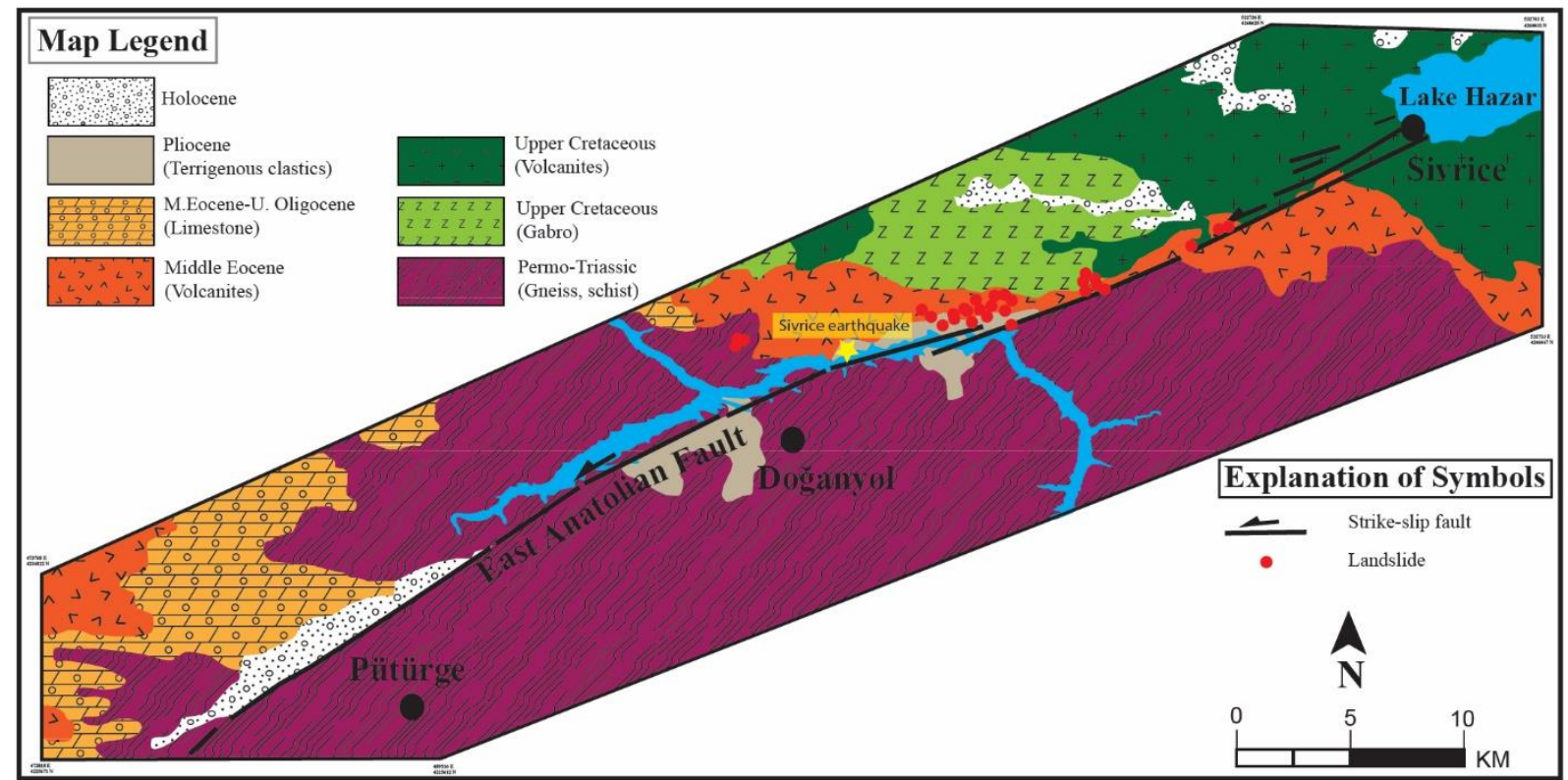

Figure 2. Geological and tectonic map for the study area (simplified from Akbaş et al. 2011 and Emre et al. 2013; Köküm and Inceöz 2018, 2020) shows distribution of landslides in geological unit and epicentre of Sivrice earthquake.

\section{Results and discussion}

\subsection{Landslides}

A landslide is defined as the movement of a mass of rock, debris, or earth down a slope (USGS, 2021). Landslides can be triggered by earthquakes, precipitation, erosion, human effect, or any combination of these factors, here I concentrate earthquake-triggered landslides. Figure 3 shows the overall distribution of landslides and other ground damage effects such as lateral spreading, cracks, and liquefaction induced by the Sivrice earthquake. Total of 30 landslides were mapped by on-ground field studies. A peak horizontal acceleration (PGA), which are calculated by AFAD, for the Sivrice and Pütürge county is $0,30 \mathrm{~g}$ at $24 \mathrm{~km}$ distant, and $0,24 \mathrm{~g}$ at $25 \mathrm{~km}$ distant respectively during the Sivrice event. In addition, apart from the direct damage caused by the earthquake, many landslides were triggered in an area of $\sim 55 \mathrm{~km} 2$.

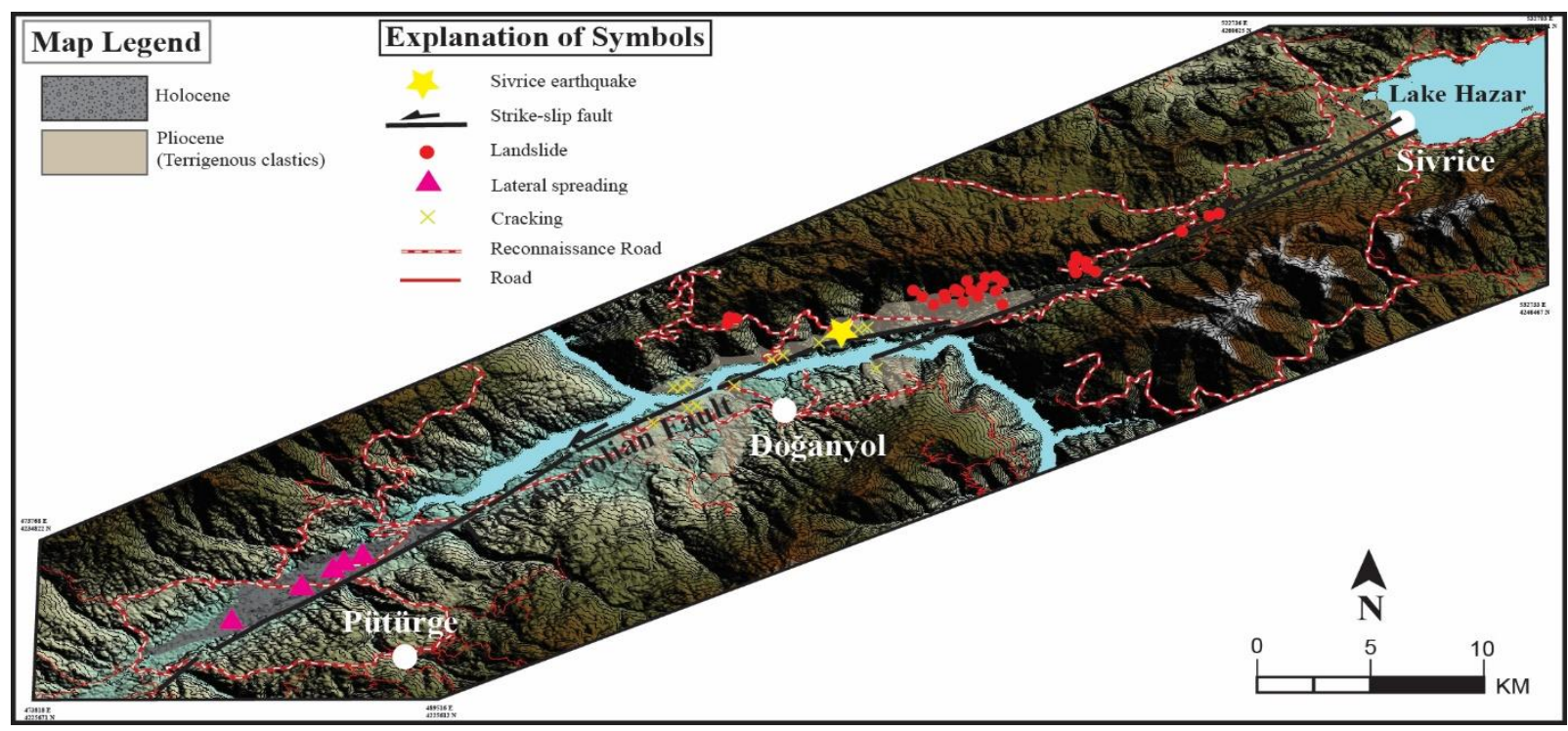

Figure 3. Main structures including the distribution of landslides, lateral spreading and other ground damaged effects triggered by the Sivrice earthquake have been highlighted. 
In the study area, different types of rock units ranging in age from Paleozoic to Holocene are exposed (Akbaş et al., 2011; Köküm, 2019; Köküm and Inceöz, 2018, 2020) (Figure 2). The oldest geologic unit is Permo-Triassic gneiss and schist, which forms a basement under the Paleozoic, Mesozoic, and Cenozoic rocks and sediments. They are very common in the southern part of the map. The late Cretaceous units are mostly composed of gabbro and volcanic rocks. Middle Eocene unit contain basaltic, andesitic rocks intercalated and lateral-vertical transitive with sedimentary succession. The geological types of contacts of the Permo-Triassic rocks and middle Eocene rocks are tectonically controlled by the EAF, hence about $10 \mathrm{~km}$ left-lateral offset accumulated along the EAF in the middle Eocene rocks. Steep cliffs cut in middle Eocene volcanic rocks are the sites of many landslides during Sivrice earthquake. The middle Eocene-Oligocene unit are mostly composed of basal conglomerate and reef limestones. The Pliocene unit is a terrigenous clastics which is observed as narrow outcrops in the study area. The Holocene unit, mostly found in the strike-slip basin, consists of poorly sorted weakly cemented conglomerates and cross-bedded coarse-grained sandstones.

Many landslides were triggered from terrace edges cut into fluvial valley fill (Figure 4). Steep topography and thin soil cover make the region susceptible to shallow debris slides and falls. In addition to the high density of landslides near the epicentral region, there were many displaced boulders on terrace surfaces that also confirm to high levels of ground shaking in this area (Figure 5a). It is also worth noting that, besides landslides failed completely, incipient landslide cracking, and cracking along ridge crests exist along the epicentral area (Figure 5b). These ground deformations were mostly observed in gentle topography.
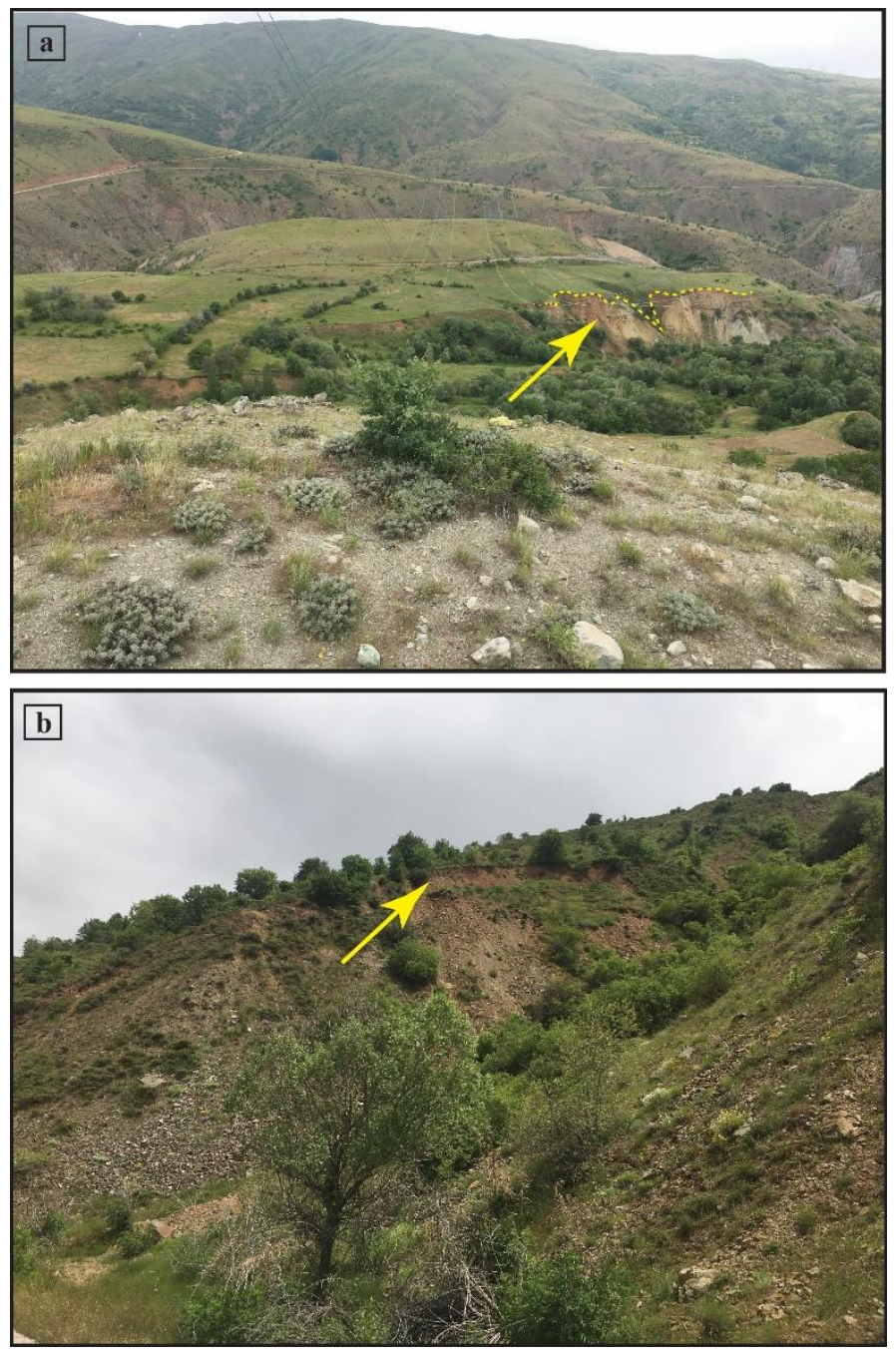

Figure 4. View of the landslides near the epicentral area induced by the Sivrice earthquake (taken 20 May, 2020). a) A large landslide was triggered from terrace edges cut into fluvial valley fill. (Location of the photo, 38022 ' 50" N, 390 10' 11" E, looking to south). b) Fresh slump scarp is visible. Arrow indicates fresh slump. (Location of the photo, $38023^{\prime} 15^{\prime}$ N, 390 10' 19' E, looking to south). 
According to the landslide inventory map prepared by MTA (General Directorate of Mineral Research and Exploration) and field observations, there are many active and paleo landslides in the region (Duman et al., 2011). The historical earthquake catalogue summarized most recently by Soysal et al., (1981) includes several destructive earthquakes on the Pütürge segment of the EAF. Presence of a particular large and group of landslides is often assumed with evidence of large historic earthquakes. This assumption would cause overestimation of a seismic hazard or underestimation of landslide hazard ignoring other triggering phenomena like precipitation (Strom, 2013).

No doubts that the Sivrice earthquake produced fewer landslides than the empirical prediction for shallow earthquakes of these magnitudes (Mw 6.8) (Tanyaş et al., 2017). Yet, similar size earthquakes that triggered fewer landslides may have not been documented. The main reason for having fewer landslides could be that in addition to geologic environments and geomorphological factors, there are already many existing paleo landslides that were thought to be largely triggered by past seismic origin in the region. Presence of a large and group of paleo landslides near the fault zone in the region supports the idea that these landslides are largely associated with past earthquakes. Magnitude as well as local geologic conditions, earthquake focal depth, and the specific ground motion characteristic of a particular event controls the numbers and distribution of landslides (Keefer, 1984).
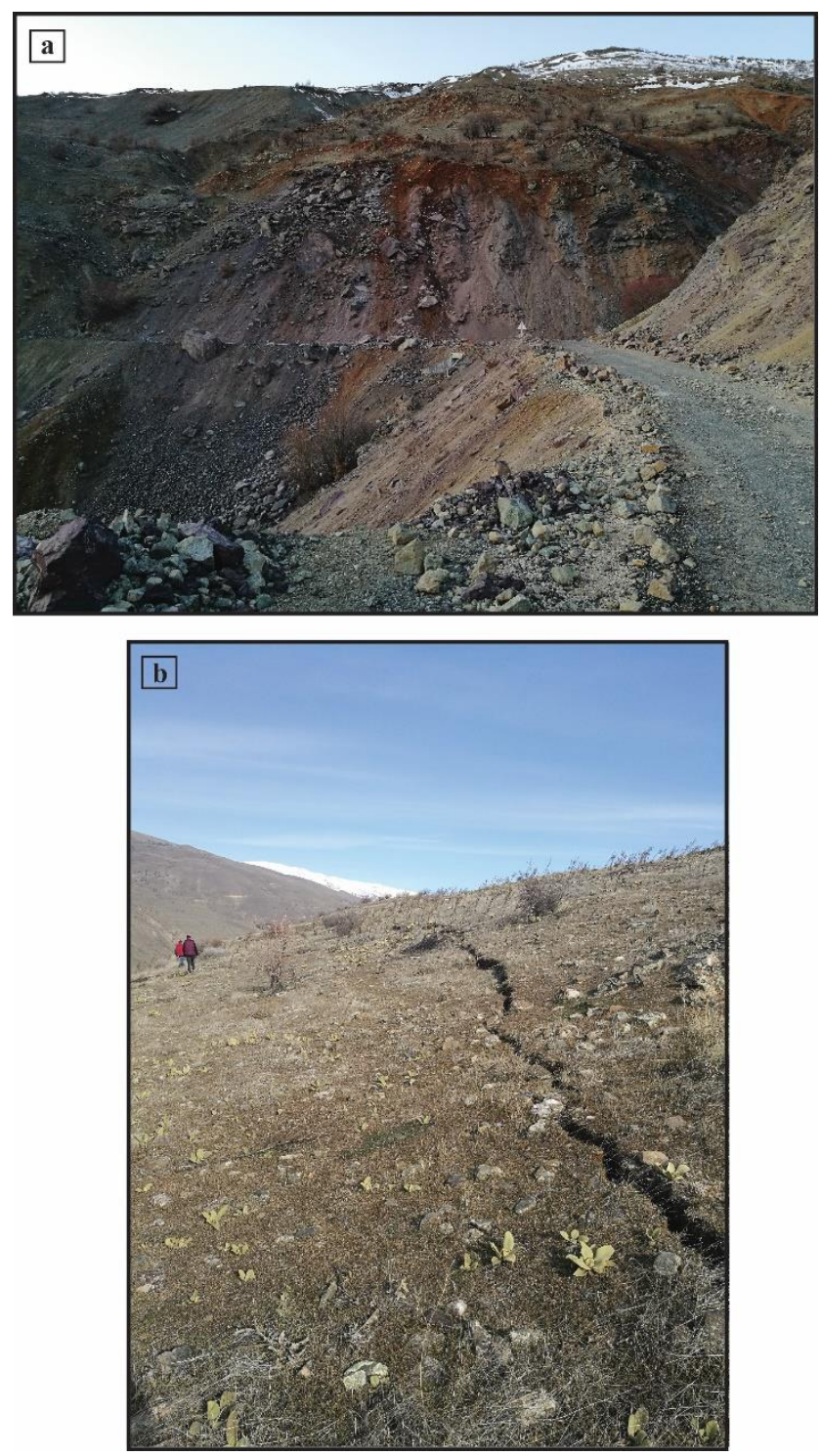

Figure 5. a) View of the displaced boulders near the epicentral area confirm to high levels of ground shaking. (taken 26 January, 2020, location of the photo, 38021 ' 59" N, 390 06' 29" E, looking to north). b) Incipient landslide cracking, and cracking along ridge crests exist along the epicentral area. (taken 27 January, 2020, location of the photo, $38019^{\prime} 40^{\prime \prime} \mathrm{N}, 39000^{\prime} 35^{\prime \prime}$ E, looking to northeast). 


\subsection{Lateral spreading}

Lateral spreading or flowing are terms referring to landslides that commonly form on gentle slopes and that have rapid fluid-like flow movement, like water (USGS, 2021). The Sivrice earthquake generated extensive lateral spreading in Holocene age river banks, and result in the ground tears, opening surface cracks and fissure on flat ground ( $>5 \%$ ground slope). Pütürge is the most prominent area that shows extensive lateral spreading, however very few sand boils were tracked (Figure 6). In this region, lateral spreading was mostly developed in the fields and coasts where outside of the settlement area.

Along the Şiro River, an $\sim 2 \mathrm{~km}$ length of river bank experienced lateral spreading and liquefaction during the Sivrice earthquake (Figure 2). Maximum lateral ground displacements at the river banks ranged from several tens of centimeters up to $1 \mathrm{~m}$. These features of lateral spreading are presented in Figure 6 where the location and width of surface cracks and fissures observed on the flat ground.
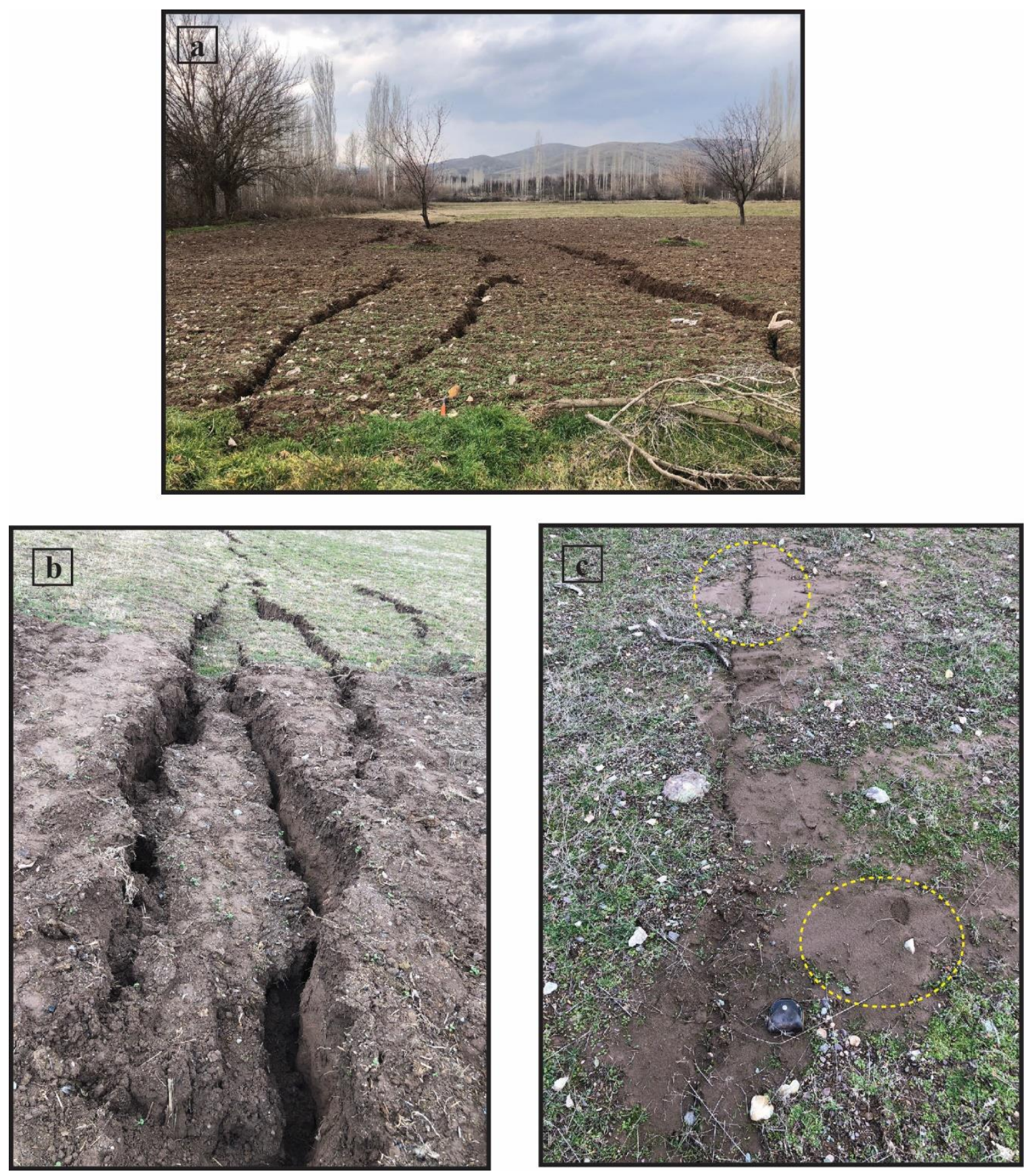

Figure 6. View of lateral spreading in Holocene age river banks near Pütürge. (taken 6 February, 2020, location of the photos, $38011^{\prime} 39$ ” N, 38046 ' 49" E, looking to southwest). a) Opening surface cracks on flat ground. b) Close view of horst and graben structures. c) Sand boils. 
On-ground field visits shows that most of the cracks run parallel to the river indicating that they are associated with lateral movement of the ground towards the river. It is also evident, however, that some cracks are concentrated at ridges and higher elevation areas, both near and away from the river, providing clear evidence that topographic features also played an important role in driving and manifestation of lateral spreading.

Large-displacement lateral spreads occurred at sites composed predominantly of fine sand, but in some instances, medium sand dominated. Most alluvial material in lateral spreads were Holocene, and a few were Pliocene.

\subsection{Surface rupture}

Surface rupture is displacement that reaches the earth's surface during slip along a fault (USGS, 2021). A main purpose of the on-ground field survey following the Sivrice earthquake was to seek evidence of surface fault rupture (surface displacement). In this work, on-ground field excursions were performed an area between Sivrice and Pütürge area. If the fault that ruptured in the Sivrice earthquake extended to the ground surface, any structures (roads, bridges, settlement, etc.) built across the faults were cut and displaced near and around the epicentral region. After detailed examination of the nearby roads and other structures, it was concluded that the Sivrice earthquake did not produce surface rupture. There certainly was cracking and slumping nearby roads, but this was the result of failure of unsupported embankment slopes.

\section{Conclusion}

Each type of earthquake induced ground deformation (landslides, lateral spreading, etc) occurs in a particular suite of geological and geomorphological environments. The following conclusions were obtained as a result of this study.

(1) The Sivrice earthquake produced fewer landslides for shallow earthquakes of these magnitudes ( $\mathrm{Mw}$ 6.8) would suggest. The main reason for having fewer landslides could be that in addition to geologic environments and geomorphological factors, there are already many existing paleo landslides that were thought to be largely triggered by past seismic origin in the region.

(2) The Sivrice earthquake triggered extensive lateral spreading in Holocene age river banks, and result in the ground tears, opening surface cracks and fissure on flat ground. There is clear concentration of cracks and fissures along the banks of the Şiro River.

(3) There is no evidence of primary surface rupture associated with Sivrice earthquake.

\section{References}

AFAD (2020). Sivrice earthquake (24 January, 2020) report. Disaster and Emergency Management Authority, Presidential of Earthquake Department. Erişim adresi https://deprem.afad.gov.tr/depremdokumanlari/1 831

Akbaş, B., Akdeniz, N., Aksay, A., Altun, İ. E., Balcı, V., Bilginer, E., Bilgiç, T., Duru, M., Ercan, T., Gedik, İ., Günay, Y., Güven, İ. H., Hakyemez, H. Y., Konak, N., Papak, İ., Pehlivan, Ş., Sevin, M., Şenel, M., Tarhan, N., Turhan, N., Türkecan, A., Ulu, Ü., Uğuz, M. F., Yurtsever, A. T. (2011). 1:1.250.000 scaled Geological map of Turkey. General Directorate of Mineral Research and Exploration Publication, Ankara-Turkey.

Allen, C. R. (1969). Active faulting in northern Turkey. Division of Geological Sciences, California. Institute. Technology, 32.

Altınlı, İ. E. (1963). Explanatory text of the geological map of Turkey of 1:500000 scale; Erzurum sheet. Ankara: Bulletin of Mineral Research and Exploration Institute.

Ambraseys, N. N. (1989). Temporary seismic quiescence: SE Turkey. Geophysical Journal 96, 311-331.

Ambraseys, N. N. and Finkel, C. (1995). The seismicity of Turkey earthquake of 19 December 1977 and the seismicity of the adjacent areas 1500-1800. İstanbul: Eren Yayıncılık ve Kitapcılık.

Ambraseys, N. N. and Jackson, J. A. (1998). Faulting associated with historical and recent earthquakes in the eastern Mediterranean region. Geophysical Journal International, 133, 390-406.

Arpat, E. and Şaroğlu, F. (1972). The East Anatolian Fault System; thoughts on its development. Bulletin of Mineral Research and Exploration 78, 33-39.

Arpat, E. and Şaroğlu, F. (1975). Türkiye'deki bazı önemli genç tektonik olaylar. Türkiye Jeoloji Kurumu Bülteni, 18(1), 91-101.

Barka, A.A. and Kadinsky-Cade K. (1988). Strike-slip fault geometry in Turkey and influence on earthquake activity. Tectonics 7(3), 663-684. 
Bletery, Q., Cavalié, O., Nocquet, J. M. and Ragon, T. (2020). Distribution of interseismic coupling along the North and East Anatolian faults inferred from InSAR and GPS data. Geophysical Research Letters, 47(16), e2020GL087775.

Dewey, J. F. and Şengör, A.M.C. (1979). Aegean and surrounding regions: complex multiplate and continuum tectonics in a convergent zone. Geological Society of America Bulletin 90, 8492.

Duman, T. Y., Çan, T. and Emre, Ö. (2011). 1/1500000 scaled Turkish landslide inventory map. Ankara: General Directorate of Mineral Reserach and Exploration, Special Publications-27.

Duman, T. Y. and Emre, Ö. (2013). The East Anatolian Fault: geometry, segmentation and jog characteristics. Geological Society, London, Special Publications, 372(1), 495-529.

Emre, Ö., Duman, T. Y., Özalp, S., Elmacı, H., Olgun, Ş. and Şaroğlu, F. (2013). Active fault map of Turkey with an explanatory text. 1:1250000 Scale. Ankara: General Directorate of Mineral Research and Exploration, Special Publication Series-30.

Hempton, M. R. (1985). Structure and morphology of the East Anatolian Transform Fault zone near Lake Hazar, southeastern Turkey. Geological Society of America Bulletin, 96, 233-243.

Herece, E. and Akay, E. (1992). The East Anatolian Fault between Karliova and Çelikhan. Petroleum Congress, Chamber of Petrological Engineering and Turkish Association, (pp. 361-372). Ankara.

Jackson, J. and McKenzie, D. (1984). Active tectonics of the Alpine-Himalayan Belt between western Turkey and Pakistan. Geophysical Journal International, 77(1), 185-264.

Keefer, D. K. (1984). Landslides caused by earthquakes. Geological Society of America Bulletin, 95(4), 406-421.

Kandilli Observatory and Earthquake Research Institute (KOERI) (2020). Instrumental earthquake activity. Erişim adresi http://www.koeri.boun.edu.tr/sismo/zeqdb.

Köküm, M., and Inceöz, M. (2018). Structural analysis of the northern part of the East Anatolian Fault system. Journal of Structural Geology, 114, 5563.

Köküm, M. (2019). Landsat TM görüntüleri üzerinden Doğu Anadolu Fay Sistemi'nin Palu (Elazığ)Pütürge (Malatya) arasındaki bölümünün çizgisellik analizi. Gümüşhane Üniversitesi Fen Bilimleri Enstitüsü Dergisi, 9(1), 119-127.
Köküm, M. and Özçelik, F. (2020). An example study on re-evaluation of historical earthquakes: 1789 Palu (Elazı̆g) earthquake, eastern Anatolia, Turkey. Bulletin of the Mineral Research and Exploration, 161(161), 157-170. DOI: 10.19111/bulletinofmre.603929

Köküm, M., and Inceöz, M. (2020). Paleostress analysis of the Yeşilyurt-Elazı ğ Fault zone and its importance for the tectonic evolution, east Turkey. Journal of Structural Geology, 104093.

Kürçer, A., Elmacı, H., Yıldırım, N. and Özalp, S. (2020). 24 Ocak 2020 Sivrice (Elâzı ğ) depremi $(m w=6,8)$ saha gözlemleri ve değerlendirme raporu. MTA Jeoloji Etütleri Dairesi. Erişim adresi https://www.mta.gov.tr/v3.0/mta/ilan/609

Lyberis, N., Yurur, T., Chorowicz, J., Kasapoglu, E. and Gundogdu, N. (1992). The East Anatolian Fault: an oblique collisional belt. Tectonophysics, 204(1-2), 1-15.

McKenzie, D. 1972. Active tectonics of the Mediterranean region. Geophysical Journal International, 30(2), 109-185.

Pousse-Beltran, L., Nissen, E., Bergman, E. A., Cambaz, M. D., Gaudreau, É., Karasözen, E. and Tan, F. (2020). The 2020 Mw 6.8 Elazı̆ (Turkey) earthquake reveals rupture behavior of the East Anatolian Fault. Geophysical Research Letters, 47(13), e2020GL088136.

Sayın, E., Yön, B., Onat, O., Gör, M., Öncü, M. E., Tunç, E. T., ... Calayır, Y. (2021). 24 January 2020 Sivrice-Elazığ, turkey earthquake: geotechnical evaluation and performance of structures. Bulletin of Earthquake Engineering, 19(2), 657-684.

Seymen, İ. and Aydın, A. (1972). The Bingöl earthquake fault and its relation to the North Anatolian Fault zone. Bulletin of the Mineral Research and Exploration 79, 1-8.

Soysal, H., Sipahioğlu, S., Kolçak, D. and Altinok, Y. (1981). A catalogue of earthquakes for Turkey and surrounding area (BC 2100-AD 1900). Final report, Project number 341, The Scientific and Technical Research Council of Turkey (TUBITAK), Ankara.

Strom, A. (2013). Use of indirect evidence for the prehistoric earthquake-induced landslide identification. In: Ugai K, Yagi H, Wakai A (Eds), Earthquake-Induced Landslides (pp 2130). Berlin: Springer.

Şaroglu, F., Emre, O. and Kuşçu, I. (1992). The East Anatolian Fault zone of Turkey. Bulletin of the Mineral Research and Exploration, 6, 99-105. 
Şengör, A. M. C., Görür, N. and Şaroğlu, F. (1985). Strike-slip faulting and related basin formation in zones of tectonic escape: Turkey as a case study. Society of Economic Paleontologists and Mineralogists Special Publication, 37, 227-264.

Tan, O., Tapirdamaz, M. C. and Yörük, A. (2008). The earthquake catalogues for Turkey. Turkish Journal of Earth Sciences 17, 405-418.

Tanyaş, H., van Westen, C. J., Allstadt, K. E., Anna Nowicki Jessee, M., Görüm, T., Jibson, R. W., ... Hovius, N. (2017). Presentation and analysis of a worldwide database of earthquake-induced landslide inventories. Journal of Geophysical Research: Earth Surface, 122. https://doi.org/10.1002/2017JF004236.

Tatar, O., Sözbilir, H., Koçbulut, F., Bozkurt, E., Aksoy, E., Eski, S., ..., Metin, Y. (2020). Surface deformations of 24 January 2020 Sivrice (Elazığ)-Doğanyol (Malatya) earthquake (mw= 6.8) along the Pütürge segment of the East Anatolian Fault zone and its comparison with
Turkey's 100-year-surface ruptures. Mediterranean Geoscience Reviews, 2(3), 385410.

US Geological Survey (USGS) (2021). Definition of geological term. Erişim adresi https://www.usgs.gov/faqs/what-a-landslideand-what-causes-one?qtnews_science_products $=0$ \#qtnews_science_products.

Westaway, R. and Arger, J. (2001). Kinematics of the Malatya-Ovacik fault zone. Geodinamica Acta, 14(1-3), 103-131.

Westaway, R. (2003). Kinematics of the middle east and eastern Mediterranean updated. Turkish Journal of Earth Sciences, 12(1).

Xu, J., C. Liu, and X. Xiong (2020). Source process of the 24 January $2020 \mathrm{Mw} 6.7$ East Anatolian Fault zone, Turkey. Earthquake. Seismological Society of America, 91(6), 3120-3128. 